\title{
INVESTIGATION OF THE HOT ROLLING PROCESS AT THE STECKEL MILL BY MEANS OF MODELING BY THE FINITE-ELEMENT METHOD
}

\author{
Oleksandr Kurpe; Volodymyr Kukhar
}

\author{
Pryazovskyi State Technical University, Mariupol, Ukraine
}

\begin{abstract}
Summary. The aim of the study is to obtain the stress distribution through the thickness of the rolled products along the deformation zone in the conditions of roughing rolling and in the conditions of quasi-stationary temperature distribution during finishing rolling at the Steckel mill. The research has been performed by the mathematical modeling based on the software application Abaqus CAE 6.14-2 and analytical modeling of the hot rolling process of coils at the Steckel mill with dimensions of $15 \times 1500 \mathrm{~mm}$, made of steel grade S355JR $+A R$, according to the requirements of EN 10025-2. The obtained deviations of the rolling force between mathematical modeling, analytical modeling and actual data have comparable results and a similar trend of changes through the passes, the average value of which does not exceed $1.54 \%$ and $-1.77 \%$. The beginning of the continuous layer formation of equivalent stress during roughing rolling has been determined, and, accordingly, the beginning of the deformation penetration through the entire thickness of the semi-rolled product has been also determined that occurs in the pass 6 when deformation equals $14 \%$.

Key words: mathematical modeling, analytical modeling, Steckel mill, steel grade S355JR, hot rolling of coils
\end{abstract}

Statement of the problem. Advanced technologies and the latest equipment, which have been developed recently, have given impetus to the production of rolled products with a new level of quality characteristics, including requirements for microstructure, shear fracture area, increased impact requirements and others. When developing a new technology and mastering a new product mix, with increased requirements, manufacturers and scientists are faced with problems that require further study. The way of solving one of these problems, namely providing increased requirements for these quality parameters, is to study the influence of the deformation degree on the stress distribution that occurs in the metal during rolling, and its penetration through the thickness of rolled products along the deformation zone at different temperatures.

Analysis of the available investigations. Among the research methods that are conducted to study the rolling process, currently the most common are analytical methods [13] and methods of mathematical modeling [4-10], which have become widespread with the development of computer technology.

The application of mathematical modeling methods in processes of metals processing by pressure allows to satisfy several purposes at the same time: to minimize expenses for research and development of technological processes in the conditions of actual production, to carry out in-depth research of processes of plastic deformation occurring in the experimental deformation zone; to compare the results of the study through the mathematical modeling with the actual results that have been obtained during production in order to identify bottlenecks in the technology. 
Among others, through mathematical modeling, in-depth study of temperature processes [11-13] has become widespread which are an integral part of the modern technology for metals pressure treatment.

Due to the modern development of different variants of technological processes, such as normalized rolling, thermomechanical rolling, with all its varieties, the principles of which are the interaction, under certain conditions, between temperature and deformation, there are still questions about their integrated study and impact on the final products quality.

The Objective of the work is to obtain the stress distribution through the thickness of the rolled products along the deformation zone in the conditions of roughing rolling and in the conditions of quasi-stationary temperature distribution during finishing rolling at the Steckel mill; comparison of calculation results obtained by the mathematical modeling with actual rolling results.

Statement of the task. To investigate the stress and strain distribution under the conditions of the rolling process at the Steckel mill by the finite-elements method; compare the calculation results of the rolling force parameters obtained by the mathematical modeling based on the software application Abaqus CAE 6.14-2 with the actual results obtained at the Steckel mill.

Mathematical model of the hot rolling process. The technological process and power characteristics of the Steckel mill at Ferriera Valsider plant, Italy have been investigated in the work. The scheme of the main technological line for the production of hot-rolled coils at Ferriera Valsider plant is shown in Figure 1.

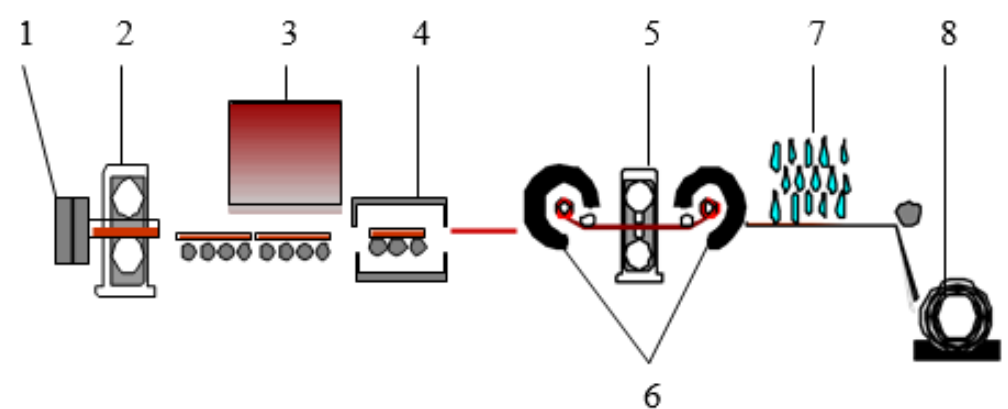
1 - stand with vertical rolls;
2 - roughing stand of 3170 ; 6 - furnace coilers;
5 - Steckel stand 1780
3 - pushing continuous heating furnace; 7 - equipment of laminar cooling;
4 - through roller furnace;
8 - coiler.

Figure 1. Scheme of the technological line for the production of hot-rolled coils at Ferriera Valsider plant

The characteristics of the experimental product mix and the actual rolling schedule are given in Table 1-3.

Table 1

The product mix of slabs and coils under study

\begin{tabular}{|c|c|c|c|c|}
\hline Heat number & Slab number & Steel grade & $\begin{array}{c}\text { Slab cross-section, } \\
\mathrm{mm}\end{array}$ & $\begin{array}{c}\text { Coil cross-section, } \\
\mathrm{mm}\end{array}$ \\
\hline 81518 & $\mathrm{~A} 1 / 02005400$ & S355JR+AR & $220 \times 1520 \times 9800$ & $15 \times 1500$ \\
\hline
\end{tabular}


Table 2

The chemical composition of the steel grade S355JR+AR under study

\begin{tabular}{|c|c|c|c|c|c|c|c|c|c|c|c|c|c|c|c|}
\hline \multirow{2}{*}{$\begin{array}{c}\text { Heat } \\
\text { number }\end{array}$} & \multicolumn{15}{|c|}{ Mass fraction, $\%$} \\
\hline & $\mathrm{C}$ & $\mathrm{Si}$ & $\mathrm{Mn}$ & $\mathrm{P}$ & $\mathrm{S}$ & $\mathrm{Cr}$ & $\mathrm{Ni}$ & $\mathrm{Cu}$ & $\mathrm{Al}$ & $\mathrm{Ti}$ & $\mathrm{Nb}$ & Mo & $\mathrm{V}$ & $\mathrm{N}$ & As \\
\hline 81518 & 0.14 & 0.023 & 1.40 & 0.014 & 0.003 & 0.05 & 0.18 & 0.02 & 0.035 & 0.005 & 0.034 & 0.01 & 0.005 & 0.007 & 0.005 \\
\hline
\end{tabular}

Table 3

The actual rolling schedule of heat number 81518 on the stands of the Steckel mill

\begin{tabular}{|c|c|c|c|c|c|c|c|c|}
\hline 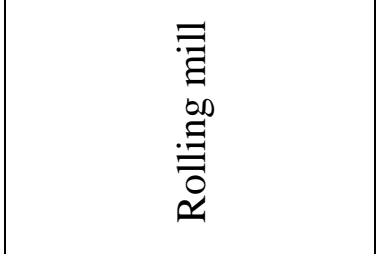 & $\tilde{\pi}_{\tilde{E}}^{\infty}$ & $\begin{array}{l}\Xi \\
\Xi \\
\bar{\Xi}\end{array}$ & 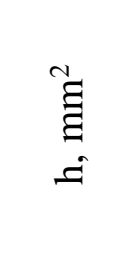 & 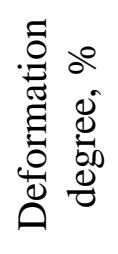 & 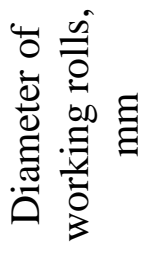 & 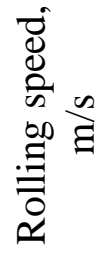 & 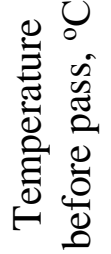 & 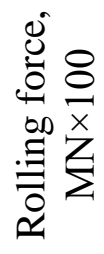 \\
\hline \multirow{11}{*}{$\begin{array}{c}\text { Two-high rolling mill } \\
3170\end{array}$} & 1 & 221.3 & 200.49 & 9.40 & 1050 & 2.20 & 1090 & 1007 \\
\hline & 2 & 200.49 & 178.82 & 10.81 & 1050 & 2.20 & 1068 & 904 \\
\hline & 3 & 178.82 & 158.36 & 11.44 & 1050 & 2.20 & 1068 & 1000 \\
\hline & 4 & 158.36 & 139.55 & 11.88 & 1050 & 2.20 & 1044 & 1017 \\
\hline & 5 & 139.55 & 120.54 & 13.62 & 1050 & 2.20 & 1073 & 1015 \\
\hline & 6 & 120.54 & 103.88 & 13.82 & 1050 & 2.20 & 1023 & 1077 \\
\hline & 7 & 103.88 & 87.23 & 16.03 & 1050 & 2.20 & 1055 & 1121 \\
\hline & 8 & 87.23 & 71.81 & 17.68 & 1050 & 2.20 & 1009 & 1243 \\
\hline & 9 & 71.81 & 57.87 & 19.41 & 1050 & 2.20 & 1027 & 1254 \\
\hline & 10 & 57.87 & 46.82 & 19.09 & 1050 & 2.20 & 1027 & 1246 \\
\hline & 11 & 46.82 & 37.16 & 20.63 & 1050 & 2.20 & 1041 & 1397 \\
\hline \multirow{3}{*}{$\begin{array}{c}\text { Fore-high rolling mill } \\
1780(\text { Steckel })\end{array}$} & 1 & 37.16 & 23.95 & 35.55 & 620 & 4.06 & 999 & 1957 \\
\hline & 2 & 23.95 & 18.98 & 20.75 & 620 & 4.06 & 958 & 1351 \\
\hline & 3 & 18.98 & 15.17 & 20.07 & 620 & 4.06 & 920 & 1195 \\
\hline
\end{tabular}

1,2 thickness before and after the pass, $\mathrm{mm}$

It should be noted that in order to exclude calculation errors associated with the fixation of the actual rolling temperature on the passes at the rolling mill, in the mathematical model in the Abaqus CAE system, the results of the analytically performed calculation have been used [14].

To build a model of metal physical and mechanical properties processed in the system $\mathrm{CAE}$ (Complete Abaqus Environment) it is necessary to specify its density, elasticity and plastic properties.

The finite-element model of a hot rolling process is built for the rolling process of steel grade S355JR+AR according to the requirements of EN 10025-2, with the chemical composition given in Table 2.

The following parameters were set in the Abaqus CAE system: density $7.8 \mathrm{E}-09 \mathrm{t} / \mathrm{mm}^{3}$; Poisson's ratio -0.3 .

The modulus of elasticity has been given depending on the metal temperature $t,{ }^{\circ} \mathrm{C}$ according to the following dependence [15]:

$$
E=\left(213.286-4.877 \times 10^{-2} t-3.33 \times 10^{-5} t^{2}-2.778 \times 10^{-8} t^{3}\right) \times 10^{3}, \mathrm{MPa}
$$


The true resistance of the metal was determined according to the method of L. V. Andreyuk and G. G. Tyulenev, by the chemical composition [16]:

$$
\sigma_{s}=S_{\sigma_{0 D}} u^{a}(10 \varepsilon)^{b}(t / 1000)^{c}
$$

where $\mathrm{u}-$ is the deformation rate, $s^{-1} ; \varepsilon-$ is the relative deformation degree, rel. units; $\mathrm{t}-$ is the deformation temperature, ${ }^{\circ} \mathrm{C} ; S_{\sigma_{0 D}}, \mathrm{a}, \mathrm{b}, \mathrm{c}$ - coefficients for each steel grade, which are determined by the corresponding dependences, taking into account the content of chemical elements in steel [16].

The transformation of the deformation resistance values (stress) $\sigma_{s}$ true , obtained by the method of L. V. Andreyuk and G. G Tyulenev, and the degree of deformation values $\varepsilon_{i n}^{p l}$ for implementation in the Abaqus CAE environment has been performed according to the following method:

$$
\begin{gathered}
\sigma_{s_{\text {true }}}=\sigma_{s}(1+\varepsilon) ; \\
\varepsilon_{\text {true }}=\ln (1+\varepsilon) ; \\
\varepsilon_{\text {in }}^{p l}=\varepsilon_{\text {true }}-\frac{\sigma_{s_{\text {true }}}}{E} .
\end{gathered}
$$

The true deformation resistance in the Abaqus CAE environment, $\sigma_{s_{\text {true }}}$, has been given depending on: the degree of deformation $\varepsilon$ in the range of $0.0 \ldots 0.8$ rel. units; deformation rates $u$ in the range of $0.0 \ldots 40.0 \mathrm{~s}^{-1}$; deformation temperature $t$ in the range of $800 \ldots 1200^{\circ} \mathrm{C}$.

In the calculations according to formula (2), to obtain zero values for the degree of deformation and the deformation rate in the Abaqus CAE system, the values respectively equal to 0.001 and 0.01 have been used.

The values of deformation resistance (stress) $\sigma_{s t r u e}$ and the deformation degree $\varepsilon_{i n}^{p l}$ have been processed by formulas (3) and (5).

To reduce the calculation time in the model, according to the software developer's recommendations, process symmetry has been used.

Processing of the finite-element modeling results consisted in the analysis of stress and deformation fields.

Reactions at the roll reference point have been used to analyze the energy parameters of the rolling process. Graphs obtained in the Abaqus CAE environment have been exported to MS Excel in numerical form and subjected to statistical processing.

The results of the calculation of the rolling process at the Steckel mill in Abaqus CAE. The calculation of steel grade S355JR+AR rolling processes from slabs with dimensions of $220 \times 1520 \times 9800 \mathrm{~mm}$ and the final coil dimensions of $15 \times 1500 \mathrm{~mm}$ in the Abaqus CAE environment has been carried out by passes for the roughing stand, rolling mill 3170 and for rolling mill 1780 with furnace coilers (Steckel), taking into account the features of technology and equipment.

The results of calculations of equivalent stress fields $S$ and equivalent plastic deformation PEEQ through the demonstration passes in the rolling mill stand 3170 are shown in Figure 2.

It should be noted that in the figures, the fields of equivalent stress $S$ have the dimension «MPa», the fields of equivalent plastic deformation PEEQ have the dimension "rel. units".

Based on the dynamics of changes in the shape of the fields, intensity or level of equivalent stress $\mathrm{S}$ in layers, we can make the conclusion as for the penetration of the 
deformation through the thickness of rolled products. As known, the final properties of the rolled products begin to form at the stage of roughing rolling. Therefore, obtaining data on the occurrence of such a phase in the metal allows to improve processes of the design, development and improvement of the technology in relation to characteristics of a particular condition and the material being processed.

When modeling the rolling schedule of steel grade S355JR+AR in mill stand 3170, the beginning of the deformation penetration into the entire depth of the semi-rolled product, in thickness, is observed in the sixth pass. Here a solid layer or stress field begins to form which equals $90 \%$ of the maximum equivalent stress in this pass, under other appropriate rolling conditions. The equivalent degree of deformation at the exit of the deformation zone, in layers, depending on the depth of penetration into the thickness of the rolled products, varies from 0.121 rel. units up to 0.208 rel. units, the difference is 0.087 rel. units.

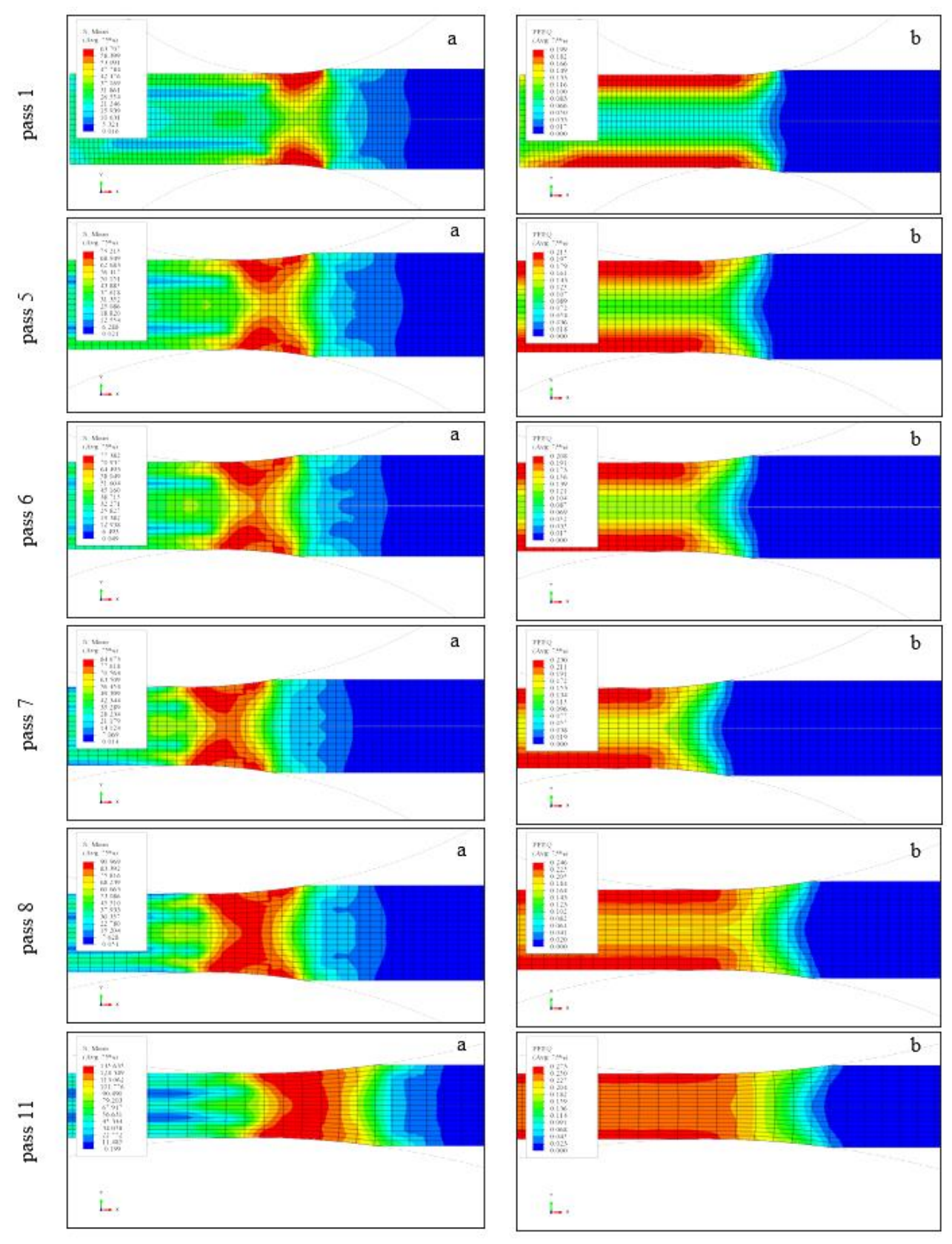

Figure 2. The results of calculations of the equivalent stress fields (a) and equivalent plastic deformation (b) in the passes at mill 3170 
Upon further rolling, in the subsequent passes, there is an increase in the length of this continuous stress field together with an increase in the value of the equivalent plastic deformation. In pass 8 the formation of a layer of maximum stress is being observed with its subsequent expansion and mixing with the stress layer, which equals $90 \%$, taking into account the size of the deformation zone. The equivalent degree of deformation at the exit of the deformation zone in layers depending on the depth of penetration into the thickness of the rolled products varies from 0.184 rel. units up to 0.246 rel. units, the difference is 0.062 rel. units.

Based on the results obtained, one can conclude that the technological efficiency of the rolling process, which is being modeled, starts to occur from the sixth pass. The deformation, which is carried out before the sixth pass, is mostly aimed only at achieving the required shape of the rolled products/semi-rolled product. The technological efficiency means the implementation of the rolling process with a significant impact on internal processes occurring throughout the thickness, and not only on the surface layers of the rolling products.

The results of the calculation of the equivalent stress fields $S$ and equivalent plastic deformation PEEQ along the passes in the rolling mill stand 1780 (Steckel) are shown in Figure 3.
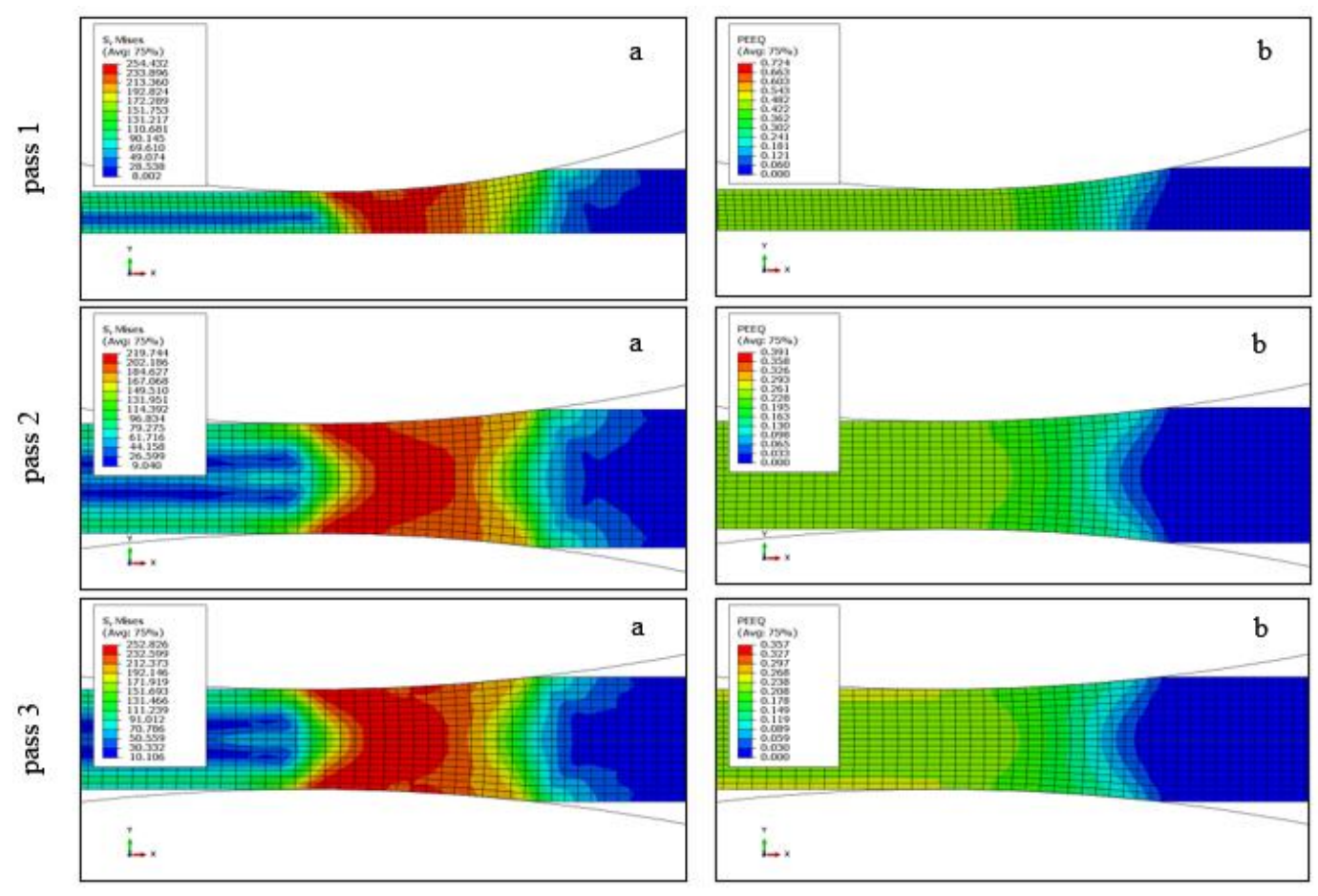

Figure 3. The results of calculations of the equivalent stress fields (a) and equivalent plastic deformation (b) in the passes at rolling mill 1780 (Steckel)

When modeling the rolling schedule of steel grade S355JR+AR in mill stand 1780 (Steckel), in all three passes there is the penetration of deformation into the entire depth of the semi-rolled product thickness under other appropriate rolling conditions. In this case, the equivalent degree of deformation at the exit of the deformation zone in layers is almost the same throughout the depth/thickness of the rolled products and has the following corresponding values: 0.422 rel. units, 0.228 rel. units, and $0.208-0.238$ rel. units.

Based on the obtained results it is possible to conclude that when rolling in mill stand 1780 (Steckel), through all passes, the penetration of deformation is carried out through the entire thickness of rolling products. The maximum equivalent stress and the stress equaled $90 \%$ of the maximum have a continuous layer throughout the entire thickness of the rolled products, taking into account the size of the deformation zone. 
The analysis of data on the results of finite-element modeling of the coil rolling process at the Steckel mill. The results of calculations in the passes obtained by the finiteelement modeling have been compared to the actual results of coils rolling with dimensions of $15 \times 1500 \mathrm{~mm}$, of steel grade S355JR+AR. Additionally, in order to identify deviations associated with the fixation of the actual rolling performance, similar calculations have been performed using the improved analytical model of the rolling process [14]. Comparison of the calculations results of temperature and rolling force is given in Table 4.

On the basis of comparative calculations it has been established that the obtained deviations of the rolling force between the two methods of calculation and the actual data have comparable results and a similar trend of changes in the passes, Figure 4 . The average value of the obtained deviations does not exceed $1.54 \%$ and $-1.77 \%$ and indicates the high accuracy of the obtained calculations results by both calculation methods.

\section{Table 4}

Comparison of actual results of coils rolling with dimensions of $15 \times 1500 \mathrm{~mm}$ produced of steel grade $\mathrm{S} 355 \mathrm{JR}+\mathrm{AR}$ at the Steckel mill with the results of calculations

\begin{tabular}{|c|c|c|c|c|c|c|c|c|c|c|c|}
\hline \multirow{2}{*}{ 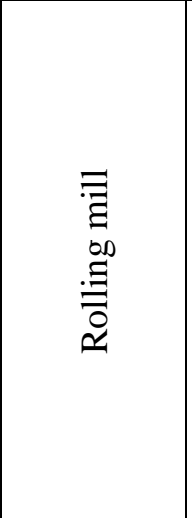 } & \multirow{2}{*}{$\begin{array}{l}n \\
\tilde{a} \\
\tilde{n}\end{array}$} & \multirow{2}{*}{$\begin{array}{l}\bar{\Xi} \\
\bar{\Xi} \\
\overline{\text { I }}\end{array}$} & \multirow{2}{*}{ 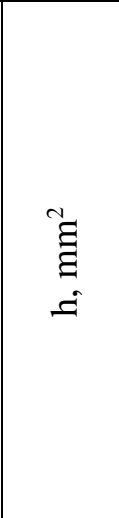 } & \multirow{2}{*}{ 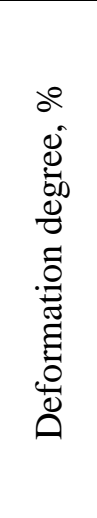 } & \multicolumn{2}{|c|}{ 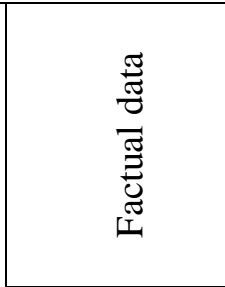 } & \multicolumn{2}{|c|}{ 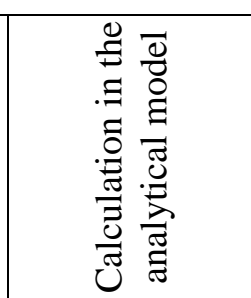 } & \multirow{2}{*}{ 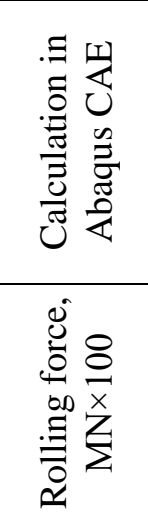 } & \multicolumn{2}{|c|}{ 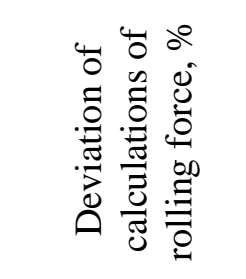 } \\
\hline & & & & & $t,{ }^{\circ} \mathrm{C}^{3}$ & 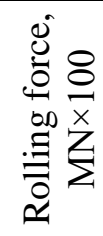 & $t,{ }^{\circ} \mathrm{C}^{3}$ & 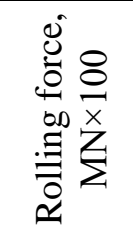 & & 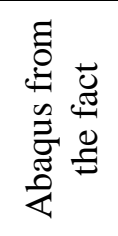 & 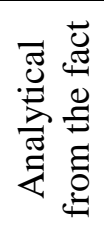 \\
\hline \multirow{11}{*}{ 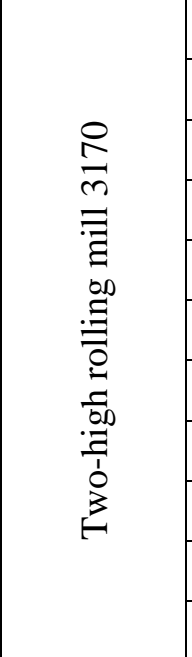 } & 1 & 221.3 & 200.49 & 9.40 & 1090 & 1007 & 1200 & 867.78 & 923.42 & 8.30 & 13.83 \\
\hline & 2 & 200.49 & 178.82 & 10.81 & 1068 & 904 & 1194 & 946.42 & 970.29 & -7.33 & -4.69 \\
\hline & 3 & 178.82 & 158.36 & 11.44 & 1068 & 1000 & 1187 & 965.31 & 963.11 & 3.69 & 3.47 \\
\hline & 4 & 158.36 & 139.55 & 11.88 & 1044 & 1017 & 1179 & 970.42 & 943.00 & 7.28 & 4.58 \\
\hline & 5 & 139.55 & 120.54 & 13.62 & 1073 & 1015 & 1169 & 1060.42 & 1011.41 & 0.35 & -4.47 \\
\hline & 6 & 120.54 & 103.88 & 13.82 & 1023 & 1077 & 1158 & 1048.15 & 981.68 & 8.85 & 2.68 \\
\hline & 7 & 103.88 & 87.23 & 16.03 & 1055 & 1121 & 1144 & 1163.62 & 1088.26 & 2.92 & -3.80 \\
\hline & 8 & 87.23 & 71.81 & 17.68 & 1009 & 1243 & 1127 & 1243.94 & 1174.54 & 5.51 & -0.08 \\
\hline & 9 & 71.81 & 57.87 & 19.41 & 1027 & 1254 & 1105 & 1341.91 & 1291.21 & -2.97 & -7.01 \\
\hline & 10 & 57.87 & 46.82 & 19.09 & 1027 & 1246 & 1076 & 1350.15 & 1288.40 & -3.40 & -8.36 \\
\hline & 11 & 46.82 & 37.16 & 20.63 & 1041 & 1397 & 1037 & 1532.49 & 1484.29 & -6.25 & -9.70 \\
\hline \multicolumn{10}{|l|}{ Average } & 1.54 & -1.23 \\
\hline \multirow{3}{*}{ 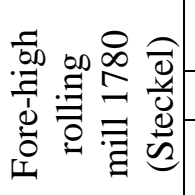 } & 1 & 37.16 & 23.95 & 35.55 & |999 & 1957 & 999 & 1900.98 & 2253.24 & -15.14 & 2.86 \\
\hline & 2 & 23.95 & 18.98 & 20.75 & \begin{tabular}{|l|}
958 \\
\end{tabular} & 1351 & 973 & 1173.79 & 1169.96 & 13.40 & 13.12 \\
\hline & 3 & 18.98 & 15.17 & 20.07 & 920 & 1195 & 931 & 1236.66 & 1202.42 & -0.62 & -3.49 \\
\hline \multicolumn{10}{|l|}{ Average } & 0.38 & -1.77 \\
\hline
\end{tabular}

1,2 thickness before and after the pass, $\mathrm{mm}$

${ }^{3}$ temperature before pass 
The analytical checking calculation of the change in the temperature of the strip along the passes, used in the mathematical modeling, confirmed the presence of significant deviations in the actual temperatures during the roughing rolling, which may occur due to the location of technological pyrometers and the presence of steam. Thus, the legitimacy of application of analytically calculated rolling temperatures for finite-element modeling has been confirmed.

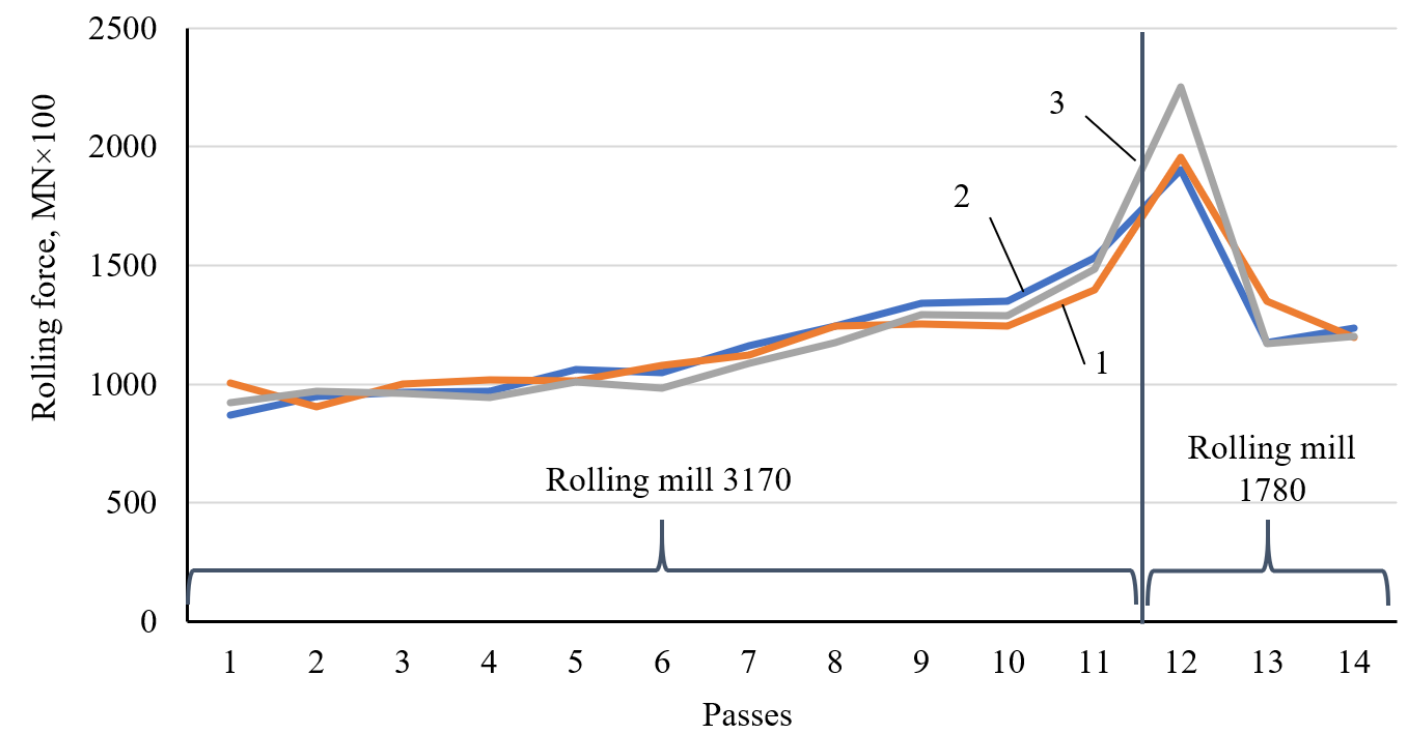

Figure 4. Changes in the rolling force in passes according to the actual data (1), according to the analytical calculations (2), according to the results of mathematical modeling (3)

It is known that the average pressure is the weigh-averaged value between the stress that appears in individual layers throughout the thickness of the semi-rolled product when rolling and the stress resulted from the influence of processes outside the contact deformation.

Based on the results of mathematical modeling, the levels of equivalent stress on each layer in the deformation zone have been determined, the processing of which in Excel allows to determine the value that is comparable to the average pressure. Based on this fact, and the results of analytical calculations at the roughing stage of rolling, we can determine the beginning of the formation of a continuous layer of equivalent stress during roughing rolling, i.e. the beginning of the penetration of deformation throughout the entire thickness of the semirolled product. The results of the calculations are given in Table 5.

The intersection between the deviation curve between the maximum level of the equivalent stress and the average pressure and the curve of variation of the deformation degree along the passes (built within the experimental limits) is the beginning and is the corresponding condition of the deformation penetration throughout the entire thickness of the semi-rolled product at roughing rolling at rolling mill 3170, Figure 5.

Thus, it has been determined that the beginning of the continuous layer formation of the equivalent stress during the roughing rolling, and accordingly the beginning of the penetration of deformation throughout the entire thickness of the semi-rolled product occurs in pass 6 under conditions of deformation equal 0.14 rel. units (14\%).

The change of the deviation in the passes from positive to negative values can be explained as the process of balancing between the increase of the equivalent stress layer in the deformation zone and the decrease, in comparison, of the influence outside the contact deformation. 
In the finishing rolling at the Steckel mill, the deformation that occurs is sufficient and penetrates the entire thickness of the rolled product. Accordingly, the deviation curves of the deviation between the maximum level of equivalent stress and the average pressure and the curve of the deformation degree change do not intersect, Figure 6.

Table 5

The calculation results to determine the beginning of the formation of a continuous layer of equivalent stress during the roughing rolling at mill 3170

\begin{tabular}{|l|c|c|c|c|c|c|c|c|c|c|c|}
\hline \multicolumn{1}{|c|}{ Parameter } & \multicolumn{7}{|c|}{ The value of the parameter by number of passes } \\
\hline \multicolumn{1}{|c|}{ Pass } & 1 & 2 & 3 & 4 & 5 & 6 & 7 & 8 & 9 & 10 & 11 \\
\hline Average pressure, $\mathrm{MPa}^{1}$ & 54.80 & 58.57 & 61.48 & 64.4670 .06 & 73.98 & 82.15 & 91.26 & 103.54 & 117.01 & 142.04 \\
\hline $\begin{array}{l}\text { Maximum level of } \\
\text { equivalent stress, } \mathrm{S}, \mathrm{MPa}\end{array}$ & 63.71 & 66.42 & 67.50 & 70.94 & 75.22 & 77.38 & 84.67 & 90.97 & 104.30 & 116.85 & 135.64 \\
\hline $\begin{array}{l}\text { Deviation between } \mathrm{S} \text { and } \\
\text { average pressure, \% }\end{array}$ & 13.98 & 11.82 & 8.92 & 9.14 & 6.85 & 4.40 & 2.98 & -0.32 & 0.73 & -0.13 & -4.72 \\
\hline \begin{tabular}{l} 
Deformation degree, \% \\
\hline
\end{tabular} & 9.40 & 10.81 & 11.44 & 11.88 & 13.62 & 13.82 & 16.03 & 17.68 & 19.41 & 19.09 & 20.63 \\
\hline
\end{tabular}

${ }^{1}$ calculated using the analytical model
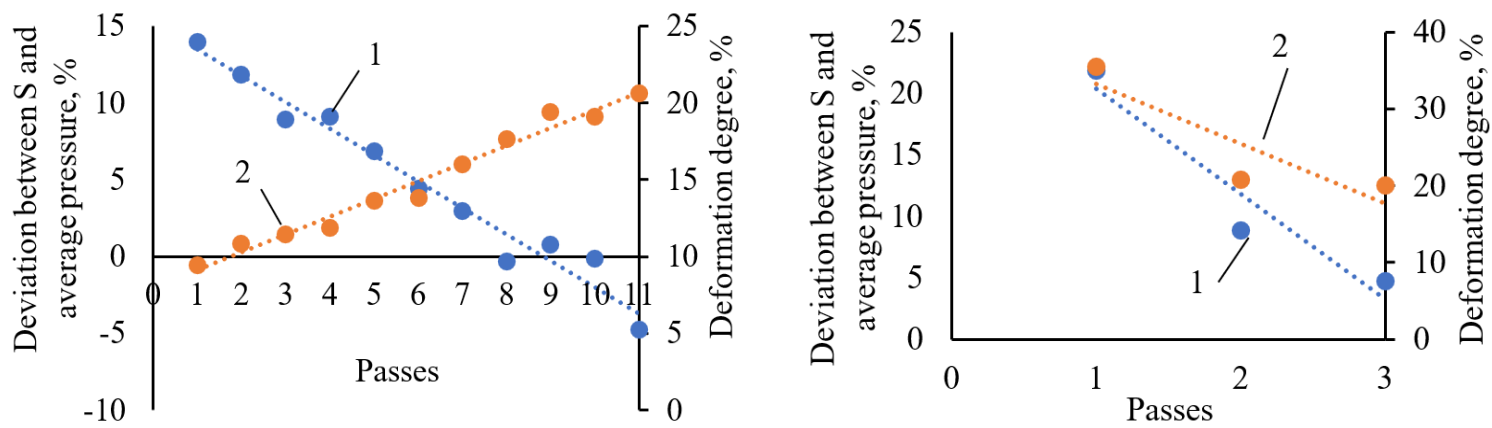

Figure 5. Determination of the beginning and conditions of the deformation penetration through the thickness of the semi-rolled product during the roughing rolling at mill 3170 based on the deviation curves between the maximum level of the equivalent stress and the average pressure (1) and the curve of variation of the deformation degree (2)

Based on the obtained results of the mathematical modeling of the rolling process at the Steckel mill by the finite-element method the line of the beginning of the deformation penetration through the entire thickness of the semi-rolled product during the roughing rolling of steel grade S355JR+AR has been established, which is equal to $14 \%$.

In the case of finishing rolling along all passes, in the conditions of quasi-stationary temperature distribution at the Steckel mill the deformation that occurs is sufficient and penetrates the entire thickness of the rolled product. This condition and the corresponding dynamics are mostly related to the thickness of the semi-rolled product during the finishing rolling.

The obtained results allow to control the processes of the internal quality and the set of rolled products properties that are to be obtained by developing appropriate technological schedules taking into account the penetration of deformation through the thickness of the rolled product. 


\section{Conclusions}

1. The study of hot rolling processes at the Steckel mill by means of the mathematical modeling by the finite-element method in the Abaqus CAE system has been performed on the example of the coils production with dimensions of $15 \times 1500 \mathrm{~mm}$ made of structural steel grade S355JR+AR, according to EN 10025-2.

2. Based on the modeling results, the distribution of stress and strain fields along the passes has been obtained. Also, the power parameters of the rolling process have been calculated. The comparison of power parameters obtained by the finite-element method and calculated by the analytical method with the actual data on the results of coils rolling with dimensions of $15 \times 1500 \mathrm{~mm}$ made of structural steel grade S355JR+AR at the Steckel mill has been performed. The average value of deviations does not exceed $1.54 \%$ and $-1.77 \%$, respectively, which proves the high accuracy of the results obtained by both methods of calculation.

3. For the first time, based on the obtained results of the rolling process mathematical modeling at the Steckel mill by the finite-element method the line of the beginning of deformation penetration through the entire thickness of the semi-rolled product during the roughing rolling of steel grade $\mathrm{S} 355 \mathrm{JR}+\mathrm{AR}$ has been determined, and it is equal to the deformation degree of $14 \%$, that corresponds to pass 6 .

4. It has been established that during finishing rolling, through all passes, in the conditions of quasi-stationary temperature distribution at the Steckel mill, the deformation that occurs is sufficient and penetrates the entire thickness of the rolled product.

5. The results obtained by the finite-element modeling method allow to control the internal quality processes and the set of rolled product properties that need to be obtained by developing appropriate technological schedules taking into account the penetration of deformation through the entire thickness of the rolled product. The obtained results can be used to develop hot rolling technology (with one or more stages of roughing rolling) at other types of mills and complexes of basic equipment with similar technological parameters.

\section{References}

1. Kim J., Lee J., Hwang S. M. An analytical model for the prediction of strip temperatures in hot strip rolling. International journal of heat mass transfer, 2009. Vol. 52, pp. 1864-1874. https://doi.org/10.1016/ j.ijheatmasstransfer.2008.10.013

2. Kurpe O. H., Kukhar V. V., Klimov E. S., Chernenko S. M. Improvement of Process Parameters Calculation for Coil Rolling at the Steckel Mill. Materials Science and Metallurgical Technology II. Materials Science Forum, 2020. Vol. 989, pp. 609-614. https://doi.org/10.4028/www.scientific.net/ MSF.989.609

3. Kurpe O. H., Kukhar V. V. Development and Optimization of Flat Products Manufacturing at Rolling Mill 3200. Materials Science and Metallurgical Technology. Materials Science Forum, 2018. Vol. 946, pp. 794-799. https://doi.org/10.4028/www.scientific.net/MSF.946.794

4. Yunbo Xu, Yongmei Yu, Xianghua Liu, Guodong Wang. Modeling of microstructure evolution and mechanical properties during hot-strip rolling of $\mathrm{Nb}$ steels. Journal of University of Science and Technology. Beijing, 2008. Vol. 15, pp. 396-401. https://doi.org/10.1016/S1005-8850(08)60075-4.

5. Schausberger F., Steinboeck A., Kugi A. Mathematical modeling of the contour evolution of heavy plates in hot rolling. Applied Mathematical Modelling, 2015. Vol. 39, pp. 4534-4547. https://doi.org/10.1016/ j.apm.2015.01.017.

6. Quan-Ke Pan, Qing-da Chen, Tao Meng, Bing Wang, Liang Gao. A mathematical model and two-stage heuristic for hot rolling scheduling in compact strip production. Applied Mathematical Modelling, 2017. Vol. 48, pp. 516-533. https://doi.org/10.1016/j.apm.2017.03.067.

7. Rudkins N., Evans P. Mathematical modelling of mill set-up in hot strip rolling of high strength steels. Journal of Materials Processing Technology, 1998. Vol. 80-81, pp. 320-324. https://doi.org/10.1016/ S0924-0136(98)00190-3.

8. Andreas Ettl, Katharina Prinz, Martin Mueller, Andreas Steinboeck, Andreas Kugi. Mathematical Model and Stability Analysis of the Lateral Plate Motion in a Reversing Rolling Mill Stand. IFAC-PapersOnLine, 2018. Vol. 51, no. 2, pp. 73-78. https://doi.org/10.1016/j.ifacol.2018.03.013. 
9. Phaniraj M. P., Behera B. B., Lahiri A. K. Thermo-mechanical modeling of two phase rolling and microstructure evolution in the hot strip mill Part I. Prediction of rolling loads and finish rolling temperature. Journal of Materials Processing Technology, 2005. Vol. 170, pp. 323-335. https://doi.org/10.1016/j.jmatprotec.2005.05.009

10. Kukhar V. V., Nikolenko R. S. Issledovanie naprjazhenno-deformirovannogo sostojanija zagotovok pri profilirovanii vypuklymi plitami s jekscentrisitetom nagruzki. Problems of Tribology, 2012. No. 3, pp. 132-136. [In Russian].

11. Daniel Weisz-Patrault. Coupled heat conduction and multiphase change problem accounting for thermal contact resistance. International Journal of Heat and Mass Transfer, 2017, pp. 595-606. https://doi.org/10.1016/j.ijheatmasstransfer.2016.08.091.

12. Daniel Weisz-Patrault, Alain Ehrlacher, Nicolas Legrand. Temperature and heat flux fast estimation during rolling process. International Journal of Thermal Sciences, 2014, pp. 1-20, https://doi.org/10.1016/ j.ijthermalsci.2013.07.010.

13. Daniel Weisz-Patrault. Inverse three-dimensional method for fast evaluation of temperature and heat flux fields during rolling process. Symposium on Modelling of Rolling Processes, France, 2012, pp. 20-22.

14. Kurpe O. H., Kukhar V. V., Zmaznyeva Ye. V. Utochnennya rozrakhunku teplovykh vtrat metalu na stanakh Stekkelya. Problems of Tribology, 2018. No. 1, pp. 78-84. [In Ukraine]. https://doi.org/ 10.20535/ 2521-1943.2018.84.12960

15. Fedorinov V. A., Satonin A. V., Gribkov Je.P. Matematicheskoe modelirovanie naprjazhenij, deformacij i osnovnyh pokazatelej kachestva pri prokatke otnositel'no shirokih listov i polos. monogr. Kramatorsk: DGMA, 2010, 244 p. [In Russian].

16. Konovalov Ju. V., Ostapenko A. L., Ponomarev V. I. Raschet parametrov listovoj prokatki. Spravochnik. Moskva: Metallurgija, 1986, 430 p. [In Russian].

\section{Список використаної літератури}

1. Kim J., Lee J., Hwang S. M. An analytical model for the prediction of strip temperatures in hot strip rolling. International journal of heat mass transfer. 2009. Vol. 52. P. 1864-1874. https://doi.org/10.1016/ j.ijheatmasstransfer.2008.10.013

2. Kurpe O. H., Kukhar V. V., Klimov E. S., Chernenko S. M. Improvement of Process Parameters Calculation for Coil Rolling at the Steckel Mill. Materials Science and Metallurgical Technology II. Materials Science Forum. 2020. Vol. 989. P. 609-614. https://doi.org/10.4028/www.scientific.net/ MSF.989.609

3. Kurpe O. H., Kukhar V. V. Development and Optimization of Flat Products Manufacturing at Rolling Mill 3200. Materials Science and Metallurgical Technology. Materials Science Forum. 2018. Vol. 946. P. 794-799. https://doi.org/10.4028/www.scientific.net/MSF.946.794

4. Yunbo Xu, Yongmei Yu, Xianghua Liu, Guodong Wang Modeling of microstructure evolution and mechanical properties during hot-strip rolling of $\mathrm{Nb}$ steels. Journal of University of Science and Technology. 2008. Vol. 15. P. 396-401. https://doi.org/10.1016/S1005-8850(08)60075-4.

5. Schausberger F., Steinboeck A., Kugi A. Mathematical modeling of the contour evolution of heavy plates in hot rolling. Applied Mathematical Modelling. 2015. Vol. 39. P. 4534-4547. https://doi.org/10.1016/ j.apm.2015.01.017.

6. Quan-Ke Pan, Qing-da Chen, Tao Meng, Bing Wang, Liang Gao A mathematical model and two-stage heuristic for hot rolling scheduling in compact strip production. Applied Mathematical Modelling. 2017. Vol. 48. P. 516-533. https://doi.org/10.1016/j.apm.2017.03.067.

7. Rudkins N., Evans P. Mathematical modelling of mill set-up in hot strip rolling of high strength steels. Journal of Materials Processing Technology. 1998. Vol. 80-81. P. 320-324. https://doi.org/10.1016/S09240136(98)00190-3.

8. Andreas Ettl, Katharina Prinz, Martin Mueller, Andreas Steinboeck, Andreas Kugi Mathematical Model and Stability Analysis of the Lateral Plate Motion in a Reversing Rolling Mill Stand. 2018. Vol. 51 . № 2. P. 73-78. https://doi.org/10.1016/j.ifacol.2018.03.013.

9. Phaniraj M. P. Thermo-mechanical modeling of two phase rolling and microstructure evolution in the hot strip mill Part I. Prediction of rolling loads and finish rolling temperature. Journal of Materials Processing Technology. 2005. Vol. 170. P. 323-335. https://doi.org/10.1016/j.jmatprotec.2005.05.009

10. Кухарь В. В., Николенко Р. С. Исследование напряженно-деформированного состояния заготовок при профилировании выпуклыми плитами с эксцентриситетом нагрузки. Проблеми трибології 2012. № 3. C. 132-136.

11. Weisz-Patrault Daniel. Coupled heat conduction and multiphase change problem accounting for thermal contact resistance. International Journal of Heat and Mass Transfer. 2017. P. 595-606. https://doi.org/10.1016/j.ijheatmasstransfer.2016.08.091. 
12. Daniel Weisz-Patrault, Alain Ehrlacher, Nicolas Legrand Temperature and heat flux fast estimation during rolling process. International Journal of Thermal Sciences. 2014. P. 1-20. https://doi.org/10.1016/ j.ijthermalsci.2013.07.010.

13. Weisz-Patrault Daniel. Inverse three-dimensional method for fast evaluation of temperature and heat flux fields during rolling process. Symposium on Modelling of Rolling Processes. France, 2012. P. 20-22.

14. Курпе О. Г., Кухар В. В., Змазнєва Є. Уточнення розрахунку теплових втрат металу на станах Стеккеля. Проблеми трибології. 2018. № 1. С. 78-84. https://doi.org/10.20535/25211943.2018.84.12960

15. Федоринов В. А., Сатонин А. В., Грибков Э. П. Математическое моделирование напряжений, деформаций и основных показателей качества при прокатке относительно широких листов и полос: моногр. Краматорск: ДГМА, 2010. 244 с.

16. Коновалов Ю. В., Остапенко А. Л., Пономарев В. И. Расчет параметров листовой прокатки: справочник. Москва: Металлургия, 1986. 430 с.

\title{
УДК 621.771.014.2
}

\section{ДОСЛІДЖЕННЯ ПРОЦЕСУ ГАРЯЧОЇ ПРОКАТКИ НА СТАНІ СТЕККЕЛЯ ШЛЯХОМ МОДЕЛЮВАННЯ МЕТОДОМ СКІНЧЕНИХ ЕЛЕМЕНТІВ}

\author{
Олександр Курпе; Володимир Кухар \\ ДВНЗ «Приазовський державний технічний університет», \\ Маріуполь, Україна
}

\begin{abstract}
Резюме. Отримано розподіл напруги по товщині прокату вздовж вогнища деформацї в умовах чорнового прокатування та в умовах квазістаціонарного розподілу температур при чистовому прокатуванні на стані Стеккеля. Дослідження виконано иляхом математичного моделювання на базі програмного додатка Abaqus CAE 6.14-2 та аналітичного моделювання процесу гарячої прокатки рулонів на стані Стеккеля розмірами $15 \times 1500$ мм зі сталі марки S355JR+AR згідно з вимогами EN 10025-2. 3a результатами моделювання отримано розподіл полів напруги та деформації по проходах, також розраховано енергосилові параметри процесу прокатки. Відхилення сили прокатки між математичним, аналітичним моделюванням та фактичними даними мають співставленні результати ци схожу тендениію змінення по проходах, середнє значення яких не перевищує $1.54 \%$ та $-1.77 \%$. Шляхом математичного моделювання та запропонованими аналітичним методом визначено початок формування суцільного шару еквівалентної напруги при чорновій прокатчі, а відповідно, $i$ початок проникнення деформації по всій товщчині заготовки, який відбувається в проході 6 при деформації, яка дорівнює 1\%. При чистовій прокатиі по всіх проходах деформачія, яка відбувається, є достатньою та проникає по всій товщині прокату. Результати, отримані методом скінчено-елементного моделювання, дозволяють керувати проиесами внутрішньої якості та комплексом властивостей прокату, які необхідно отримати шляхом розроблення відповідних технологічних режимів з урахуванням проникнення деформацї по товщчні прокату. Отримані результати можуть бути використані для розроблення технології гарячої прокатки (з однією або кількома стадіями чорнової прокатки) на інших типах станів та комплексів основного устаткування зі схожими технологічними параметрами.

Ключові слова: математичне моделювання, аналітичне моделювання, стан Стеккеля, марка сталі S355JR, гаряча прокатка рулонів.
\end{abstract}

https://doi.org/10.33108/visnyk_tntu2020.02.068

Отримано: 25.05.2020 